\title{
A OBRA GORZIANA DA DÉCADA DE 2000 \\ E A SUA RELAÇÃO COM A NOVA CRÍTICA DO VALOR
}

\author{
THE GORZIAN WORK OF THE 2000S \\ AND ITS RELATION WITH THE NEW CRITIQUE OF VALUE
}

Nuno Miguel Cardoso Machado*

[0] capitalismo do saber gera em si e para além de si a perspectiva de sua possível supressão. Em seu âmago, germina uma semente comunista: [...] uma "economia da doação anarco-comunista” (GORZ, 2005a, p. 69).

\section{Introdução}

A importância de André Gorz no contexto do debate sociológico contemporâneo acerca da crise da sociedade do trabalho é incontestável (GOLLAIN, 2000; CASTEL, 2013). Todavia, a ligação entre a obra tardia de Gorz e a denominada Nova Crítica do Valor (NCV) é na maioria das vezes escamoteada. Esta corrente de pensamento surgiu no final da década de 1970/meados da década de 1980 e tem raízes na crítica da economia política de Marx e na teoria crítica da Escola de Frankfurt. Os seus principais representantes são Jean-Marie Vincent, Moishe Postone e Robert Kurz que, sem qualquer contato entre si, chegaram a conclusões bastante similares no decurso das suas investigações da sociedade capitalista (JAPPE, 2006).

Este artigo tem como principais objetivos analisar detalhadamente a obra Gorziana da década de 2000 e discutir a sua relação estreita com a NCV. 0 trabalho insere-se, pois, na tradição disciplinar da Sociologia das Ideias (CAMIC; GROSS, 2004) e da História das Ideias (SKINNER, 1969). Na qualidade de estudo baseado em textos (SOUTHGATE, 2003), as técnicas de investigação utilizadas serão a análise do-

\footnotetext{
* Estudante do doutoramento em Sociologia Económica e das Organizações (Instituto Superior de Economia e Gestão, Universidade de Lisboa/Lisboa/Portugal) e investigador do SOCIUS - Centro de Investigação em Sociologia Económica e das Organizações. Licenciado em Economia (ISEG) e mestre em Sociologia Económica e das Organizações (ISEG).nuno.cocas.machado@gmail.com.
} 
cumental e a análise de conteúdo (QUIVY; CAMPENHOUDT, 2005). Proporemos uma grelha de leitura original que permitirá a análise comparativa de várias dimensões da teoria da NCV (ver Quadro 1, item 2.4), e aferiremos quais as principais convergências e divergências que existem entre Gorz e a NCV (seção 3).

Adeus ao Proletariado (GORZ, 1982) representou a primeira grande ruptura no pensamento de André Gorz. Ao longo da década de 1980, Gorz critica ferozmente a glorificação do trabalho e a "religião do proletariado" do marxismo tradicional. Por sua vez, na década de 1990, a sua trajetória intelectual foi marcada pela continuidade relativamente às principais conclusões retiradas de Metamorfoses do Trabalho (GORZ, 1989a) e, inclusive, por uma toada reformista e pessimista (GORZ, 1994; 1999a). Gorz acaba por se entrincheirar numa definição bastante redutora de socialismo enquanto restrição do funcionamento do "mercado autorregulado" e da esfera de incidência da racionalidade econômica.

A década de 2000 representa uma segunda grande ruptura no pensamento Gorziano, no sentido de uma nova radicalização, algo de invulgar no percurso teórico de um autor (ainda mais se atendermos ao fato de Gorz estar a entrar na casa dos 80 anos). Neste artigo sustentarei a tese de que os principais fatores que contribuiram para essa mudança foram a influência do seu amigo de longa data Jean-Marie Vincent - nomeadamente através dos debates suscitados em torno revista Futur Antérieur, ao longo dos anos 1990 - e, acima de tudo, a descoberta da obra de Moishe Postone e de Robert Kurz.
As críticas de Vincent, segundo as quais Gorz não levava em conta nas suas obras a "importância do general intellect", conduziram o autor a uma revisão da sua posição. A "inteligência coletiva" torna-se a principal força produtiva, pelo que a "apropriação coletiva" dos meios de produção se torna uma perspectiva "bastante menos abstrata” (GORZ, 2002a, p. 78).

Ademais, no denominado "capitalismo cognitivo", o conhecimento tornou-se uma das principais forças produtivas. Dado que o conhecimento não é redutível a uma quantidade de trabalho abstrato e é reprodutivel - nomeadamente sob a forma de software praticamente sem custos, ele "compromete a validade das categorias econômicas chaves e indica a necessidade de estabelecimento de uma outra economia" (GORZ, 2005a, p. 9). Essa é a temática de $O$ Imaterial $^{1}$ (GORZ, 2005a), que constitui a reelaboração de um texto escrito para um congresso internacional acerca da "sociedade do conhecimento", promovido pela Fundação Heinrich Böll (GORZ, 2004, p. 209).

Quanto a Kurz e a Postone, em uma entrevista concedida em 2006, Gorz assumirá explicitamente:

o que me interessa hoje em dia [...] é a "Nova Interpretação da teoria crítica de Marx" publicada por Moishe Postone [a obra Time, Labor and Social Domination] [...]. Se pudesse fazer um voto, seria o de vê-la traduzida juntamente com os livros publicados por Robert Kurz. (GORZ, 2006, p. 4)

Em relação a Postone, Gorz qualifica a sua obra simplesmente de "magistral"

1. Na nossa análise de $O$ Imaterial, socorremo-nos da tradução portuguesa efetuada por Celso Azzan Jr. (GORZ, 2005a). Essa versão difere contudo da original em francês, publicada em 2003, pois já incorpora as modificações e adendas do autor para a publicação em alemão do livro. 
(GORZ, 2007a, p. 13); no que se refere a Kurz, Gorz diz que o autor é "provavelmente o melhor teórico crítico das transformações do capitalismo e da sua crise atual" (GORZ, 2010a, p. 182), e qualifica de "profético" o seu livro 0 Colapso da Modernização (GORZ, 2010a, p. 132).

Postone e Kurz revelar-se-ão, pois, fundamentais para as análises que Gorz empreenderá até a sua morte, em setembro de 2007. Essa influência é particularmente evidente em Ecologica (GORZ, 2010a), uma coletânea de artigos publicada a título póstumo ${ }^{2}$. Em primeiro lugar, pode-se destacar a apropriação da distinção, basilar para a $\mathrm{NCV}$, entre riqueza (material e imaterial) e valor econômico. 0 objetivo primordial do modo de produção capitalista não é a criação de riqueza, mas a criação de valores mercantis. Assim, é preciso romper essa “ditadura do valor" (GORZ, 2005b, p. 1) vigente nas sociedades produtoras de mercadorias da modernidade (GORZ, 2005b, p. 2).

Em segundo lugar, Gorz aceita a teoria da crise proposta por Robert Kurz: o capitalismo atingiu, finalmente, o seu limite interno absoluto. A 3a Revolução Industrial - aquela da microeletrônica - implica a eliminação crescente de trabalho vivo do processo produtivo. Assiste-se, portanto, à abolição da substância do capital: o trabalho abstrato. Esta crise atinge não apenas os países capitalistas avançados, mormente os Estados Unidos, mas também as economias emergentes - os chamados BRICS (Brasil, Rússia, Índia, China e África do Sul).

Em terceiro lugar, Gorz defende, no seguimento das teses de Kurz e Postone, que a superação emancipatória do capitalismo exige a abolição de todas as categorias mercantis: trabalho, valor, dinheiro, mercadoria. Uma vez que a riqueza já não é mensurável em termos de "valor de troca" (GORZ, 2002a, p. 90), é necessário construir uma nova sociedade fundada sobre o bem comum, i.e., assente em "decisões coordenadas em função de critérios definidos pela concertação" social (GORZ, 2004, p. 207). Desse modo, a produção poder-se-ia apresentar imediatamente como uma "atividade cooperativa" e como "produção social sem ter de passar pelo mercado e pela forma do valor" (GORZ, 2004, p. 207).

\section{André Gorz: a crise estrutural do capi- talismo}

\subsection{0 trabalho imaterial e a economia do conhecimento}

Em O Imaterial, Gorz defende que o “capitalismo moderno", baseado na valorização de grandes massas de "capital fixo material”, está a dar lugar a um "capitalismo pós-moderno", baseado na valorização de um "capital dito imaterial, qualificado também de "capital humano" ou capital cognitivo (GORZ, 2005a, p. 15).

Essa transformação faz-se acompanhar por metamorfoses correspondentes na forma do trabalho. 0 "trabalho abstrato simples”, considerado pela economia política clássica a fonte do valor, é substituído pelo "trabalho complexo"; o trabalho material, "mensurável em unidades de produtos por unidades de tempo", cede o seu lugar ao

2. Apesar do título, esse livro não acrescenta nada de verdadeiramente novo relativamente ao pensamento ecológico de Gorz. Praticamente todos os ensaios que abordam as questões ecológicas já tinham sido publicados nas décadas anteriores (GORZ, 2010a, p. 77-97, 98-118; GORZ, 2010b). 
trabalho imaterial que já não é regido pelos padrões de medida tradicionais (GORZ, 2005a, p. 15). “A informatização da indústria tende a transformar o trabalho em gestão de um fluxo contínuo de informações" (GORZ, 2005a, p. 17).

No "capitalismo cognitivo", o conhecimento assume-se como a principal força de produção e como a principal fonte de criação de riqueza (GORZ, 2005a, p.17). Doravante, a riqueza depende cada vez mais do "nível geral da ciência e do progresso da tecnologia" (MARX, 2011 apud Gorz, 2005a, p. 16); o processo de produção já não pode ser concebido, na sua essência, como um "processo de trabalho" (GORZ, 2005a, p. 16). Na chamada "economia do conhecimento", os produtos da atividade social já não são primariamente "produtos do trabalho cristalizado, mas sim do conhecimento cristalizado" (GORZ, 2005a, p. 29).

Ao contrário do trabalho social geral, não é possível mensurar o conhecimento em "unidades [de tempo] abstratas simples”, ou seja, o conhecimento não é "redutivel a uma quantidade de trabalho abstrato de que ele seria o [...] produto" (GORZ, 2005a, p. 29). 0 valor das "forças de trabalho" e dos "seus produtos" tornase, pois, indeterminável e a impossibilidade de padronizar e estandardizar a produção de conhecimento traduz-se numa tentativa desesperada de "quantificar a sua dimensão qualitativa” (GORZ, 2005a, p. 29-30). Nesse contexto, "as escalas de avaliação do trabalho se tornam um ciclo de contradições" (GORZ, 2005a, p. 29).

A crise da medição do trabalho engendra inevitavelmente a crise da medição do valor. Quando o tempo socialmente necessário a uma produção se torna incerto, essa incerteza não pode deixar de repercutir sobre o valor de troca do que é produzido. 0 caráter cada vez mais qualitativo, cada vez menos mensurável do trabalho, põe em crise a pertinência das noções de "sobretrabalho" e de "sobrevalor" [ou mais-valia]. A crise da medição do valor põe em crise a definição da essência do valor. Ela põe em crise, por consequência, o sistema das equivalências que regula as trocas comerciai. (GORZ, 2005a, p. 30, grifo nosso).

A utilização do conhecimento sob a forma de capital tem acompanhado o desenvolvimento da sociedade capitalista desde o seu começo. Não obstante, hoje em dia,

Todo conhecimento passível de formalização pode ser abstraído de seu suporte material e humano, multiplicado quase sem custos na forma de software e utilizado ilimitadamente em máquinas que seguem um padrão universal. Quanto mais se propaga, mais útil ele é à sociedade. Seu valor mercantil, ao contrário, diminui com a sua propagação e tende a zero: o conhecimento torna-se um bem comum acessivel a todos (GORZ, 2005a, p. 10).

0 conhecimento é "virtualmente gratuito" (GORZ, 2005a, p. 36) na medida em que o custo marginal do software é "desprezível” (GORZ, 2005a, p. 37). Ademais, o conhecimento pode exercer

em si mesmo, e por si mesmo, uma ação produtiva na forma de programas de computador. Ele pode organizar e gerir as interações complexas entre um grande número de atores e de variáveis; pode conceber e conduzir as máquinas, as instalações e os sistemas de produção flexíveis; [...], substituindo o trabalho vivo, material ou imaterial, por trabalho acumulado. (GORZ, 2005a, p. 37, grifo do autor) 
A produção computadorizada permite, pois, poupar trabalho "em proporções gigantescas, inimagináveis” (GORZ, 2005a, p. 37). Assim, o conhecimento informático “destrói muito mais 'valor' do que serve para criar. [...] [E]le economiza quantidades imensas de trabalho social remunerado, e consequentemente diminui, ou mesmo anula, o valor de troca monetária de um número crescente de produtos e serviços” (GORZ, 2005a, p. 37, grifo do autor).

Podemos concluir que o conhecimento não se presta a ser tratado como mercadoria, porquanto o seu valor não pode ser aferido de acordo com o tempo de trabalho despendido na sua criação (GORZ, 2005a, p. 10). Desse modo, "o "capitalismo cognitivo' é a crise do capitalismo” (GORZ, 2005a, p. 37, grifo do autor), dado que "a criação de valor e a criação de riqueza se afastam uma da outra de modo cada vez mais visível” (GORZ, 2005a, p. 11).

Em $O$ Imaterial, Gorz estabelece ainda uma diferença crucial entre conhecimento e saber. 0 conhecimento refere-se aos "conteúdos formalizados, objetivados, que, por definição, não podem pertencer às pessoas" (GORZ, 2005a, p. 16); ele remete-nos para um objeto, ou seja, é "transitivo, 'objetivo"” (GORZ, 2004, p. 210).

Já o saber, por sua vez,

[...] é feito de experiências e de práticas tornadas evidências intuitivas, hábitos; e a inteligência cobre todo o leque das capacidades que vão do julgamento e do discernimento à abertura de espírito, à aptidão de assimilar novos conhecimentos e de combiná-los com os saberes (GORZ, 2005a, p. 17).

Ele remete-nos para as capacidades de um "sujeito vivo" (sujet vivant). 0 saber é, deste modo, uma "capacidade prática". 0 saber é sempre um saber-fazer, um saber -agir, um saber comunicar e se comportar (GORZ, 2004, p. 210) Trata-se de uma competência que não implica necessariamente a formalização ou a codificação de conhecimentos.

Segundo Gorz, uma cultura é tão mais rica "quanto mais os saberes comuns de que ela é tecida lhe permitam integrar, transformar conhecimentos novos em saberes" (GORZ, 2005a, p. 32). 0 objetivo último é alcançar uma sociedade do conhecimento na qual a diferença entre conhecimentos e saberes se esbata em benefício de uma "relação de fecundação recíproca" (GORZ, 2004, p. 211).

\subsection{0 limite interno do capitalismo e a ex- plosão do capital fictício}

Em Ecologica, Gorz faz uma leitura mais sofisticada da crise capitalista, apoiando-se nas análises de Robert Kurz (GORZ, 2010a, p. 134, 137, 182). Segundo Gorz, a computadorização e a automatização permitem produzir quantidades crescentes de mercadorias com quantidades decrescentes de trabalho. Até aqui nada de novo (GORZ, 1985); mas a conclusão que Gorz retira desse fato é agora inequívoca: menos trabalho significa menos valor (e menos dinheiro).

Suponha-se que, num dado momento, a produtividade duplica. É necessário [apenas] metade do trabalho que era necessário anteriormente para produzir o mesmo volume de mercadorias. Mas o valor desse mesmo volume tenderá a diminuir também para metade e, mantendo-se constante a taxa de exploração, o volume do lucro tenderá a diminuir na mesma proporção. A questão é que apenas o trabalho vivo é capaz de criar valor; e, acima de tudo, apenas a força de trabalho vi- 
va é capaz de criar um valor mais elevado do que o seu próprio ou, por outras palavras, [de criar] mais-valia. Esta é a fonte do lucro. Para que o volume do lucro não diminua, a empresa terá de duplicar a taxa de exploração mantendo constante o nível de produção, ou de duplicar a sua produção mantendo a taxa de exploração constante. Na prática, ela procura combinar a intensificação da exploração com um aumento da produção (GORZ, 2010a, p. 146-147).

Desse modo, à medida que a produtividade do trabalho aumenta, o número de trabalhadores em que assenta a valorização de um dado volume de capital diminui. Assim, para evitar que a massa de lucro diminua, a produtividade da população ativa em constante regressão terá de aumentar a uma taxa superior à taxa de declínio da força de trabalho (GORZ, 2010a, p. 122). 0 capitalismo coloca-nos perante um "paradoxo aparente": cada aumento da produtividade acarreta a necessidade de um novo aumento da produtividade - e assim sucessivamente - para que se possa impedir a queda dos lucros (GORZ, 2010a, p. 22-23).

0 capitalismo aproxima-se do seu "limite interno, da sua extinção”, em virtude da "desmaterialização do trabalho e do capital”' (GORZ, 2010a, p. 120). 0 capital esbarra no seu "limite histórico" quando "o número de trabalhadores produtivos de capital cai para níveis tão baixos que o capital já não é capaz de se reproduzir e o lucro diminui drasticamente (collapses)” (GORZ, 2010a, p.
122); por outras palavras, a produção e o investimento deixam de ser "suficientemente rentáveis” (GORZ, 2010a, p. 23).

Segundo Gorz, as estatísticas de emprego não devem enganar-nos a este respeito. 0 volume do "trabalho produtivo", i.e., produtivo de mais-valia, tem diminuído drasticamente (GORZ, 2010a, p. 121). Os trabalhadores produtivos não serão mais do que $10 \%$ da população ativa dos países desenvolvidos (GORZ, 2010a/2008, p. 121-122). Mais de $25 \%$ da atividade econômica global é efetuada por 200 multinacionais, que empregam apenas 0,75\% da população mundial (GORZ, 2010a, p. 122). Os serviços pessoais, por exemplo - que representam cerca de 55\% da população ativa norte-americana -, não criam qualquer valor adicional. A sua remuneração é deduzida da mais-valia criada, pelo que representa um "rendimento secundário” (GORZ, 2010a, p. 121).

0 capitalismo enfrenta também o seu "limite externo", isto é, a impossibilidade de encontrar empreendimentos lucrativos para o capital num contexto em que o "volume de mercadorias [...] tem de crescer pelo menos tão rapidamente quanto a produtividade", pois o valor contido em cada mercadoria individual é cada vez menor (GORZ, 2010a, p. 122). ${ }^{4}$

A regressão da "acumulação produtiva" de capital é ilustrada, por exemplo, pelo fato de cerca de metade dos lucros das empresas norte-americanas derivarem de operações nos mercados financeiros. As 500 empresas listadas no índice da Standard and Poor's

3. Kurz falará de "dessubstancialização do valor".

4. Normalmente, o "limite externo" do capitalismo não é entendido como a impossibilidade de encontrar novos mercados, mas como um limite natureza ecológica ou "material": devido à diminuição do valor contido em cada mercadoria, a massa de mercadorias que serve de suporte à valorização do valor teria de aumentar infinitamente. 
possuem 631 bilhões ${ }^{5}$ de dólares em "reservas líquidas” que não são investidos por falta de retorno (GORZ, 2010a, p. 23). Uma vez que a "economia real" já não é capaz de valorizar o volume total de capital acumulado, uma parte substancial do capital é obrigado a assumir a forma de "capital financeiro" e a valorizar-se ficticiamente (GORZ, 2010a, p. 23-24). Desta forma, ao contrário do que é comum afirmar-se, a crise econômica não se deve à especulação ou à falta de regulação, mas à incapacidade de reprodução do capital(ismo) (GORZ, 2010a, p. 26).

0 volume do capital financeiro representa cerca de 160 trilhões de dólares, três a quatro vezes o valor do PIB global. Este valor, inteiramente fictício, é baseado nas "expectativas" de crescimento da economia.

A bolsa de valores converte o crescimento futuro, os lucros futuros das empresas e os preços futuros dos ativos e das propriedades em capital, juntamente com os ganhos resultantes das reestruturações, fusões e aquisições de empresas (GORZ, 2010a, p. 24). A capitalização das "expectativas de lucro e de crescimento" sustenta o nível crescente de dívida e alimenta a economia com "liquidez" que resulta da "reciclagem bancária de lucros fictícios” (GORZ, 2010a, p. 25) Os EUA, em particular, baseiam o seu crescimento econômico na dívida (interna e externa); e esta dívida acaba por ser o motor do crescimento global, nomeadamente da China (ver o item 1.3).

A "indústria financeira" limita-se, pois, a criar "dinheiro sem substância" através da compra e venda de ativos, ou seja, da criação de "bolhas especulativas" (GORZ, 2010a, p. 123). A ficção parece superar a realidade até o dia inevitável em que as bolhas rebentam e o colapso ameaça o sistema bancário e o "sistema de crédito global”, o que, por sua vez, implica períodos de “depressão econômica” cada vez mais longos (2010a, p. 25).

Podemos concluir que a valorização do capital depende crescentemente de "artifícios” financeiros e cada vez menos da produção e venda de mercadorias. A riqueza criada não é passível de ser aprisionada por muito mais tempo sob a "forma do valor" ou sob a "forma da mercadoria" (2010a, p. 125). Neste sentido, a "contração da economia baseada no valor de troca” já é uma realidade e exacerbar-se-á no futuro. A questão consiste apenas em saber se o colapso do capitalismo assumirá a forma de uma "crise catastrófica que nós suportaremos passivamente, ou de uma escolha social auto-organizada, fundadora de uma economia e de uma civilização que superem o trabalho assalariado e as relações mercantis" (2010a, p. 125).

Concluirei este ponto com duas observações. Em primeiro lugar, a descrição da crise estrutural do capitalismo efetuada por Gorz é assumidamente inspirada pela teoria da NCV e, em particular, pela de Robert Kurz (GORZ, 2007a, p. 4).Também para o autor alemão as dificuldades de acumulação de capital na esfera real - em virtude da crise do valor e da produção mercantil - levam o capital, desesperadamente, a "simular” a sua acumulação na esfera financeira (KURZ, 1995). Todavia, a explosão do capital fictício e do crédito não resolvem o

5. Como é sabido, o "bilhão" anglo-saxônico corresponde aos "mil milhões" utilizados em Portugal (1 000000 000). Por sua vez, o "trilhão" anglo-saxônico corresponde ao "bilião" utilizado no país (1 000 000000 000). 
problema de base, apenas o protelam por mais algum tempo.

Em segundo lugar, é de salientar a transformação sofrida pela análise do "capital financeiro" por parte de Gorz. Em Misérias do Presente, Riqueza do Possivel o autor possuía uma visão diferente, mais "tradicional" entre a esquerda, encarando o capital financeiro como um "parasita que devora a economia" (GORZ, 1999a, p. 5-6, 14-22), i.e., como a causa e não como a consequência da crise.

\subsection{EUA e BRICS: os motores gripados da economia mundial}

Na perspectiva de Gorz, o crescimento econômico norte-americano, nomeadamente durante a década de 1990, foi baseado numa política que não está ao alcance de mais nenhuma nação e que, mais cedo ou mais tarde, terá consequências nefastas. À semelhança das outras economias ocidentais, os EUA padecem de uma "procura solvente" insuficiente. Todavia, esta limitação foi contornada através da acumulação de dívida, ou seja, da pura e simples impressão de dinheiro (GORZ, 2010a, p. 164). Para evitar que a procura interna declinasse e que a sua economia entrasse em recessão, a Reserva Federal encorajou os agregados familiares a endividarem-se junto dos seus bancos e a consumirem aquilo que esperavam ganhar no futuro (GORZ, 2010a, p. 164-165).

Concomitantemente, a escalada dos mercados bolsistas promovida pela new economy possibilitou uma autêntica "fúria de consumo": o valor elevado da sua carteira de títulos acionistas permitiu aos indivíduos "transformar o seu capital fictício em renda real” (GORZ, 2005a, p. 43).

0 sobre-endividamento da "classe média" foi e continua a ser o "principal motor do crescimento" norte-americano e, consequentemente, da economia global (GORZ, 2010a, p. 164). Em 1995, por exemplo, o consumo das famílias norte-americanas superou em 350 bilhões de dólares os seus rendimentos auferidos. Este consumo - que não estava obviamente ligado a nenhum "trabalho produtivo" - refletiu-se num déficit da Balança de Transações Correntes da ordem dos 100 bilhões de dólares anuais e que, uma década depois, atingiria a soma mirabolante de 600 bilhões de dólares (GORZ, 2010a, p. 164).

0 valor astronômico das importações norte-americanas inundou o mundo de liquidez (puramente fictícia). No fundo, os EUA "financiavam uma dívida com outras dívidas": o dinheiro sem substância criado pela Reserva Federal e, posteriormente, emprestado às famílias, servia para alimentar 0 volume crescente das importações norte-americanas (GORZ, 2010a, p. 164). Os EUA são o exemplo extremo dos "artifícios financeiros" (referidos no ponto anterior) que o capitalismo utiliza para adiar o seu colapso.

A implosão da new economy sucedeu em 2000, naquele que foi o maior crash bolsista desde 1929 (GORZ, 2005a, p. 43). Não obstante, a quebra das Bolsas não produziu nenhum "saneamento", como é normalmente afırmado. Com efeito, começou desde então a formar-se uma nova bolha financeira - desta vez ligada ao imobiliário - que acabaria por conduzir à grave crise econômica e financeira que atravessamos desde 2008. Na realidade,

o capitalismo caminha à beira do abismo, empurra uma montanha de dívidas nunca antes vista à sua frente, evita o estrangulamento com a multiplicação de dinheiro sem substância e, com acrobacias de curto prazo, procura contornar a pergunta que a ele 
se coloca: Como a sociedade da mercadoria pode perdurar, se a produção de mercadorias utiliza cada vez menos trabalho e põe em circulação cada vez menos moedas? (GORZ, 2005a, p. 43).

Segundo o autor, a resposta é evidente: esta sociedade não pode continuar a funcionar por muito mais tempo. E os denominados BRICS não escapam à lógica capitalista. Quanto se fala dos "países emergentes", não deve ser esquecido, segundo Gorz, que o desenvolvimento capitalista em países como o Japão ou a Coreia do Sul ocorreu "antes da globalização neoliberal, antes da revolução microeletrónica, e num período caraterizado pelo crescimento sustentado das várias economias do Norte". Os mercados em expansão dos países ricos alimentaram o boom das exportações das economias então emergentes (GORZ, 2010a, p. 142).

Todavia, desde o final dos anos 1970, as condições mudaram completamente. Em virtude de um conjunto de fatores, as exportações para os países mais ricos já não podem ser o principal motor do crescimento dos países do Sul. Em primeiro lugar, os mercados dos países do Norte já não estão em franca expansão. Em segundo lugar, a globalização neoliberal dificulta aos países emergentes o estabelecimento de qualquer espécie de protecionismo da sua agricultura e das suas indústrias domésticas face à concorrência dos países do Norte. Mediante a crescente abertura das suas economias para "atrair investimento estrangeiro", os países do Sul passam a estar integrados numa dinâmica global que escapa completamente ao seu controle (GORZ, 2010a, p. 143).

De acordo com Gorz (2010a, p.143-144),

a era das chamadas indústrias trabalho-intensivas está a chegar ao fim. Os salários bai- xos dos países do Sul já não são suficientes para conquistar quotas de mercado. Hoje em dia, praticamente toda a produção industrial exige uma elevada intensidade de capital - e, portanto, um investimento substancial.

Last but not least, a competitividade das empresas depende muito mais do que sucedia no passado de uma

infraestrutura logística muito dispendiosa: vias de comunicação, redes de transportes, de energia e de telecomunicações, administrações e serviços públicos eficientes, centros de investigação e de formação - em suma, daquilo que Marx designava pelos faux frais da economia, que têm de ser financiados pela mais-valia produzida pela indústria (GORZ, 2010a, p.144).

Se examinarmos o denominado "milagre chinês" com mais atenção, verifıcamos que a China não constitui nenhuma exceção a este estado de coisas. Com efeito, existe um enorme defasamento entre infraestrutura logística e de serviços e as necessidades da economia chinesa. 0 desemprego está a aumentar dramaticamente, em virtude de a industrialização ter arruinado a produção rural (GORZ, 2010a, p. 144). A Organização Internacional do Trabalho estima que o desemprego urbano na China alcance a cifra de $20 \%$ e com tendência para aumentar. Aliás, os produtos chineses apenas poderão igualar em termos de qualidade os produtos do Norte se o recurso à mão de obra barata for substituído pela computadorização e pela automatização, i.e., por uma produção mais capital-intensiva e, portanto, que economiza muito trabalho (GORZ, 2010a, p. 145).

$\mathrm{Na}$ China, tal como na Índia e cada vez mais no Ocidente, o modelo de crescimento pós-fordista enriquece cerca de $20 \%$ da po- 
pulação, mas em torno dos seus "enclaves hipermodernos” são geradas vastas zonas de pobreza e de exclusão social que são terreno fértil para o crime e para a marginalidade. 0 “crescimento" não é de modo algum a resposta para a "armadilha da modernização neoliberal” (GORZ, 2010a, p. 145).

Em suma, o "mundo em vias de desenvolvimento" não salvará - como é vaticinado habitualmente - o capitalismo (nem salvará a si mesmo) através de uma "industrialização geradora de pleno emprego" (GORZ, 2010a, p.131). A mesma lógica que tornou obsoleta a força de trabalho nos países industrializados - substituindo-a por tecnologias cada vez mais eficientes aplicar-se-á às economias emergentes, pois elas terão de reger-se pelos mesmos princípios de "competitividade" e munir-se de um vasto conjunto de infraestruturas de base para sobreviverem no mercado mundial. Por outras palavras, essas economias terão de igualar (ou superar) os níveis de produtividade das economias mais avançadas, pelo que "o pleno emprego do tipo fordista não é reproduzível pelo pós-fordismo digital” (GORZ, 2010a, p. 131-132).

Concluirei este ponto com uma observação. Na sua análise da economia norte-americana, Gorz aborda de relance o chamado "circuito do déficit": os EUA criam dinheiro sem substância, inteiramente fictício, com o qual compram mercadorias estrangeiras e, depois, recebem parte desse dinheiro de volta com a compra de obrigações (títulos do tesouro) por parte de países estrangeiros, nomeadamente a China e o Japão. Ora, esta análise da dinâmica da economia global é em tudo reminiscente da análise empreendida por Robert Kurz (1995).

\section{A nova crítica do valor}

0 marxismo tradicional esteve sempre refém de uma crítica reduzida do capitalismo. 0 capitalismo é entendido meramente na base da propriedade (jurídica) privada dos meios de produção por parte dos capitalistas e da respectiva exploração "subjetiva" dos trabalhadores, mediante a apropriação da mais-valia que estes produzem. Assim, trata-se de "expropriar os expropriadores", de retirar dos "parasitas da sociedade" a mais-valia produzida pelo "trabalho produtivo honesto".

0 instrumento para isso, o "motor da história”, é constituído pela "luta de classes", pela elevação do proletariado a "sujeito da história” responsável pela construção de uma sociedade assente numa ontologia do trabalho. 0 marxismo tradicional consubstancia-se na crítica da distribuição injusta da mais-valia produzida e na oposição da "anarquia do mercado" a uma planificação central do (tempo de) trabalho da sociedade. Desse modo, utilizando a terminologia empregada por Robert Kurz, o marxismo tradicional apropriou-se apenas do núcleo “exotérico" da teoria de Marx (KURZ, 2001)

A NCV surge em finais da década de 1970/meados da década de 1980 quando Jean-Marie Vincent (na França), Moishe Postone (nos EUA) e Robert Kurz (na Alemanha) chegam, sem qualquer contato entre si, a conclusões bastante semelhantes na sua análise da sociedade capitalista (JAPPE, 2006). Ao contrário do marxismo tradicional, a NCV revê-se no núcleo "esotérico" (KURZ, 2001) da teoria de Marx: o escândalo já não é o "roubo" pelos capitalistas da mais-valia produzida pelos trabalhadores, mas a própria produção de valor e o próprio trabalho enquanto substância desse mesmo valor. Recuperando a teoria do fe- 
tichismo de Marx, a NCV empreende uma crítica radical do "sistema produtor de mercadorias da modernidade", evidenciando a necessidade de abolir as suas categorias de base, que tendem a ser ontologizadas, inclusive pelos autodenominados marxistas: valor, dinheiro, mercadoria, trabalho, Estado, mercado etc.

Se as sociedades pré-capitalistas eram marcadas por relações de dominação direta, no contexto de um fetichismo de natureza religiosa, o capitalismo é caracterizado por uma dominação impessoal, quasi-objetiva (POSTONE, 2003). Estamos na presença de uma "segunda natureza", na qual as relações sociais se autonomizam e se erguem como um poder estranho. 0 capital, erigido em "sujeito automático" (MARX, 1996, p. 174), escapa ao controle dos seres humanos e subjuga-os. Hegel defendia que não eram os seres humanos que pensavam, mas o "Espírito" ou a "Ideia" que se fazia pensar através dos indivíduos. No capitalismo sucede de fato algo de semelhante: os seres humanos não agem livremente, mas são as categorias capitalistas que agem através dos indivíduos. 0 verdadeiro sujeito é o valor, a mercadoria.

Na ótica da NCV, a oposição capital/ trabalho é imanente ao sistema capitalista, pois capital e trabalho são as duas faces da mesma moeda. 0 trabalho é a substância do capital, pelo que não se trata de libertar o trabalho, mas de nos libertarmos do trabalho. A emancipação humana virá não da elevação do trabalho como princípio supremo da humanidade, mas da sua abolição. É preciso libertar o intercâmbio ou "metabolismo com a natureza” (MARX, 1996, p. 297) e a produção de riqueza material dos grilhões do valor e da abstração trabalho tal sociabilidade humana reificada, da loucura de uma "metafísica real” (KURZ, 2004).

\subsection{Jean-Marie Vincent}

Jean-Marie Vincent (1934-2004) esteve durante toda a sua vida ligado à academia. Vincent foi professor na Universidade de Paris VIII, onde dirigiu durante vários anos o departamento de Ciências Políticas, que fundou em 1968. 0 autor esteve sempre ligado a movimentos trotskistas, mas a sua principal influência foi a teoria crítica da Escola de Frankfurt (que constituiu, aliás, o tema da sua tese de doutorado). Vincent foi um dos principais divulgadores da Escola de Frankfurt na França, tendo publicado a primeira análise detalhada desta corrente de pensamento nesse país (VINCENT, 2002).

No seu artigo seminal, "La domination du travail abstrait" (VINCENT, 1977), e na sua magnum opus, Critique du travail: le faire et l'agir (VINCENT, 1987), Vincent critica o que designa por "fetiche do trabalho", partilhado tanto pela sociedade capitalista como pelo socialismo real (e pela ortodoxia marxista). No seu entendimento, mais do que libertar o trabalho e a produção, a humanidade precisa "libertar-se da produção" e abolir o trabalho (VINCENT, 1993). Ao contrário do que é comum afirmar-se, o autor preconiza que é a realidade capitalista que é "economicista” e não a teoria de Marx, que se limita a espelhar (criticamente) o funcionamento do capitalismo (VINCENT, 2001).

A temática do fetichismo está no cerne da sua análise. Segundo Vincent, sob o capitalismo a sociabilidade dos seres humanos impõe-se-lhes "por detrás das costas" ("par dessus la tête des hommes"), ou seja, as ações individuais efetuam inconscientemente a síntese social capitalista:

Não pode, pois, tratar-se de atribuir à subjetividade dos capitalistas o papel principal na 
dinâmica da acumulação. Tudo se passa, diz Marx, como se um imenso autómato imprimisse o seu movimento à economia e à sociedade, controlando e refreando as iniciativas humanas (VINCENT, 1990a, p. 13).

Em suma, na ótica de Vincent,

a sociedade capitalista [...] é essencialmente modelada pelas formas assumidas pelo trabalho; as atividades dos indivíduos tornamse atividades intercambiáveis enquanto participantes de um trabalho geral abstrato, maleável até ao infinito, isto é, mensurável, e divisivel sejam quais forem as circunstâncias. 0 próprio capital não é mais que trabalho abstrato, cristalizado ou acumulado, cuja posse decide acerca do emprego do trabalho e da sua repartição entre os diferentes tipos de atividade. No espírito de Marx, a sociedade capitalista é por excelência uma sociedade da abstração onde os indivíduos comunicam e pautam as suas trocas passando por automatismos sociais que escapam ao seu controlo (VINCENT, 1990b, p. 151).

Nesse sentido, também o Estado, sob o capitalismo, se ergue como uma instituição estranha que domina os indivíduos. Vincent supera a visão simplista do Estado preconizada pelo marxismo tradicional. 0 Estado não é um mero instrumento a serviço dos interesses subjetivos da classe capitalista; estabelece-se uma relação funcional entre o Estado moderno e o processo de acumulação do capital (VINCENT, 1979).

Finalmente, refira-se que Vincent tem grandes reservas em relação à teoria da crise de Marx. Segundo Vincent, esta teoria representa uma visão catastrofista - e até determinista - do desenvolvimento do modo de produção capitalista. É errado, portanto, postular a existência de um limite interno absoluto no que tange à valorização do valor (VINCENT, 2001).

\subsection{Moishe Postone}

Moishe Postone (1942-), à semelhança de Vincent, esteve durante toda a sua vida ligado ao ensino universitário e à investigação. Postone é professor na Universidade de Chicago e um historiador conceituado. Em 1978, Postone publicou um artigo seminal intitulado "Necessity, labor and time: a reinterpretation of the Marxian critique of capitalism" (POSTONE, 1978) que estabeleceu as linhas gerais do seu programa de investigação nas décadas seguintes. Esta investigação teve como ponto alto a publicação, em 1993, da sua principal obra: Time, labor, and social domination: a reinterpretation of Marx's critical theory (POSTONE, 2003).

Dados os limites de espaço, salientarei apenas cinco aspectos-chave da teoria Postoniana:

Postone demarca-se daquilo que designa por "marxismo tradicional". 0 marxismo professa uma crítica do capitalismo do "ponto de vista do trabalho" (from the standpoint of labor), entendendo o conceito marxiano de trabalho de forma positiva e glorificando o proletariado. Postone, por seu turno, empreende uma critica do trabalho (critique of labor). À semelhança de Marx, Postone capta a natureza historicamente específica do "trabalho abstrato": este é responsável pela socialização negativa capitalista.

Postone foi pioneiro na distinção - central para a NCV - entre riqueza (material e imaterial) e valor. 0 valor é uma forma de riqueza "abstrata" - à semelhança do trabalho que o cria - e específica do capitalismo. Segundo Postone, Marx estabeleceu uma teoria do valor-trabalho e não uma teoria trans-histórica 
do trabalho criador de riqueza. A divergência entre riqueza e valor econômico está no cerne da crise da sociedade capitalista.

Para além das antinomias trabalho concreto/ trabalho abstrato e valor de uso/valor, Postone dedica uma atenção especial à dinâmica temporal do capitalismo. De acordo com o autor, a inter-relação entre tempo concreto, tempo abstrato e tempo histórico origina uma dinâmica que designa por "treadmill dynamic". Utilizando a passadeira rolante como metáfora, em que é preciso continuar a correr para ficar sempre no mesmo sítio, Postone descreve o processo (irracional) impelido pela concorrência capitalista: para manterem a sua competitividade, as empresas têm de aumentar continuamente a sua produtividade (e a sua produção).

Postone rompe com o esquema base/superestrutura nuclear para o marxismo tradicional. $\mathrm{Na}$ ótica do autor, as categorias capitalistas (mercadoria, valor, trabalho etc.) são categorias a priori no sentido kantiano do termo: expressam simultaneamente relações sociais particulares e formas de pensamento. Assim, é preciso superar os modos de ser/agir/pensar apriorísticos e fetichistas que caracterizam o capitalismo.

Postone teoriza o denominado "antissemitismo estrutural”. 0 autor alerta para os perigos de um pseudoanticapitalismo (que, historicamente, atingiu o seu auge com o nazismo, mas que continua a orientar as visões de grande parte da esquerda) que opõe o "trabalho produtivo honesto" ao "capital financeiro rapinante”. Esta visão de mundo maniqueísta tende a imputar a um determinado grupo social a responsabilidade pela crise econômica, pelo que pode desembocar facilmente na procura de "bodes expiatórios" (POSTONE, 1986).

\subsection{Robert Kurz}

Robert Kurz (1943-2012) - ao contrário de Vincent e de Postone - foi ao longo de toda a sua vida um escritor e ensaísta autônomo, nunca procurando uma carreira acadêmica. Depois de concluir os seus estudos universitários em filosofia, pedagogia e ciência política, teve as profissões mais variadas: motorista de veículos pesados, taxista e trabalhador a tempo parcial na parte técnica de um jornal. Em 1986 publica o seu artigo seminal intitulado "A crise do valor de troca” (KURZ, 2014b/1986). Todavia, apenas na década de 1990, após a publicação de $O$ Colapso da Modernização (KURZ, 1999/1991) - que lhe granjeou alguma notoriedade na Alemanha e no Brasil - se dedicará em tempo integral à teoria crítica.

Kurz esteve ligado à criação das duas revistas teóricas mais importantes no campo da NCV. Em 1986, é um dos membros fundadores da revista Crítica Marxista, que, a partir de 1990, adotará o nome com que ficou conhecida: Krisis. Robert Kurz foi sempre o principal impulsionador da revista Krisis e do grupo de discussão homônimo a ela associado. Em 2004 ocorre uma cisão no Grupo Krisis, e Robert Kurz, juntamente com alguns dos principais membros ex-Krisis (Roswitha Scholz, Claus Peter Ortlieb, Anselm Jappe etc.), funda uma nova revista intitulada Exit! - Crise e Crítica da Sociedade da Mercadoria, que continua a ser publicada até aos dias de hoje.

Tal como Vincent e Postone, Kurz toma como ponto de partida a teoria do valor e a análise do fetichismo da mercadoria empreendida por Marx. Até ao final da década de 1990, com algumas exceções, o Grupo Krisis postula o que poderemos designar por crítica do valor (wertkritik) "em sentido estrito”. Assim, há uma crítica da forma- 
mercadoria, do valor enquanto forma de riqueza fetichista, do trabalho (enquanto "substância do capital"), da noção de um sujeito revolucionário apriorístico (mormente, o proletariado) e do Estado.

Nesse sentido, a mais-valia é entendida como um fim em si mesmo irracional e não como algo que é apropriado injustamente pelos capitalistas e que, portanto, deva ser reclamado pelos operários. 0 "trabalho abstrato" é encarado como uma metafísica real (KURZ, 2004), como um puro dispêndio de energia humana - de "cérebro, músculos, nervos” (MARX, 1996, p. 173) - sem atentar ao seu conteúdo. 0 trabalho é um processo tautológico cujo objetivo central é a criação de valor (econômico). As lutas sociais não devem, pois, ser feitas no interior das categorias capitalistas - como fez historicamente o movimento operário -, mas devem visar a sua superação prática. Neste contexto, o Estado não deve ser contraposto ao mercado, nem a economia à política: ambos os polos representam as duas faces da mesma moeda; a política não possui modos de atuação autônoma, pois depende inteiramente das "receitas fiscais" e, portanto, de um processo de valorização bem-sucedido (KURZ, 1994).

No início da década de 2000, Kurz procura aprofundar a crítica do Iluminismo entendido "enquanto expressão ideológica e legitimatória das categorias de socialização negativa do sistema moderno produtor de mercadorias" (LAMAS, 2011), i.e., enquanto (ir)racionalidade historicamente específica do capitalismo - e a crítica da forma-sujeito que tinha introduzido num ensaio de 1993, intitulado "Dominação sem sujeito” (KURZ, 1993). De acordo com Kurz, a forma-sujeito moderna não é de modo algum neutra: o sujeito da modernidade é estruturalmente Masculino, Branco, Oci- dental ("MBO"), monetário e concorrencial.

No quadro da crítica do Iluminismo e da forma-sujeito, Kurz procura igualmente aprofundar a noção de uma "dissociação" sexualmente conotada introduzida por Roswitha Scholz no seu artigo seminal de 1992, intitulado "0 valor é o homem" (SCHOLZ, 1996/1992). Segundo Scholz, a forma-sujeito moderna pressupõe uma determinada relação entre os sexos: supremacia masculina evocada no domínio da Razão, do cálculo econômico e do pensamento abstrato e delegação histórica na mulher da emotividade, espontaneidade, sensibilidade e irracionalidade. 0 capitalismo deve, por conseguinte, ser entendido enquanto "patriarcado produtor de mercadorias": a esfera econômica, estruturalmente definida como masculina, pressupõe a existência de uma esfera dissociada, estruturalmente definida como feminina.

A esfera dissociada é composta por todas as atividades que escapam à racionalidade econômica e à lógica da produtividade: esfera doméstica - entendida como o local de "repouso do guerreiro" do trabalho e da concorrência - e um conjunto de atividades não produtivas do ponto de vista capitalista: saúde, educação, cuidados com idosos e com crianças, alimentação, limpeza etc.

Note-se que a entrada massiva das mulheres no mercado de trabalho - que é, antes de tudo, anacrônica, visto que ocorre numa altura em que o trabalho se encontra justamente em crise -, não desmente a relação de dissociação, pois: a) as mulheres são forçadas a interiorizar e a adotar os mesmos comportamentos "masculinos" para serem bem-sucedidas na sua profissão; b) a maior parte das mulheres são "duplamente socializadas", acumulando o seu emprego com o desempenho das tare- 
fas domésticas, com o papel de mãe etc.; c) apenas um núcleo marginal de mulheres aquelas de classe superior - é capaz de se eximir às tarefas domésticas e ao cuidado dos filhos, delegando-as a outras mulheres (empregadas domésticas, creches etc.) que, por sua vez, são "duplamente socializadas"; d) existe uma desigualdade estrutural a nível salarial, i.e., as mulheres ganham substancialmente menos do que os homens com qualifıcações e competências similares.

$\mathrm{Na}$ ótica de Kurz, a crítica do valor (wertkritik) desenvolvida na década de 1990 deve então ceder lugar à crítica do valor-dissociação (wert-abspaltung), de maior abrangência. Os últimos três artigos publicados por Robert Kurz na revista Krisis versam precisamente sobre a crítica do Iluminismo e da dissociação: "Razão sangrenta” (KURZ, 2002), "Ontologia negativa” (KURZ, 2003b) e "Tábula rasa” (KURZ, 2003c). ${ }^{6}$ Estes artigos produziram um enorme mal-estar no seio de alguns membros do Grupo Krisis, que discordam dos novos desenvolvimentos da teoria de Kurz e pretendem continuar envolvidos na crítica do valor em sentido estrito, conduzindo à cisão já mencionada e à criação da Revista e do Grupo Exit!.

\subsection{Análise comparativa dos autores}

No Quadro 1 estão sintetizadas as principais dimensões das teorias de cada autor. Como se constata, todos os autores adotam (com algumas modificações originais) a teoria do valor-trabalho de Marx e têm na teoria crítica da Escola de Frankfurt a sua principal herança teórica. Aquilo que designamos, no item 2.3, por crítica do valor "em sentido estrito" é igualmente partilhada pelos três autores: crítica do trabalho, crítica do fetichismo da mercadoria, crítica do valor (i.e., o valor é entendido como uma forma de riqueza historicamente específica), concepção da dominação capitalista como uma dominação impessoal (aquilo que Marx denomina por "sujeito automático"), crítica do Estado e crítica do mercado. A única exceção é a crítica Vincentiana do Estado e, em particular, da política. Se Vincent supera a visão redutora do Estado do marxismo tradicional enquanto instrumento a serviço da "classe dominante" e apreende a relação funcional do Estado com o processo de acumulação de capital, o autor não é capaz de dar o passo decisivo no sentido da antipolítica Kurziana e continua, por vezes, a contrapor "uma outra política” aos ditames do capital.

6. Estes ensaios serão posteriormente reunidos (juntamente com “Dominação sem sujeito”) e publicados no livro Razão sangrenta (KURZ, 2010) 


\begin{tabular}{lccc} 
Dimensões da Teoria Crítica & Jean-Marie Vincent & Moishe Postone & Robert Kurz \\
Teoria do Valor-Trabalho (Marx) & $\mathrm{X}$ & $\mathrm{X}$ & $\mathrm{X}$ \\
Escola de Frankfurt & $\mathrm{X}$ & $\mathrm{X}$ & $\mathrm{X}$ \\
(herança teórica) & & & $\mathrm{X}$ \\
Crítica do trabalho (abstrato) & $\mathrm{X}$ & $\mathrm{X}$ & $\mathrm{X}$ \\
Crítica do fetichismo da mercadoria & $\mathrm{X}$ & $\mathrm{X}$ & $\mathrm{X}$ \\
Crítica do valor & $\mathrm{X}$ & $\mathrm{X}$ & $\mathrm{X}$ \\
(distinção riqueza/valor) & & & $\mathrm{X}$ \\
$\begin{array}{l}\text { Dominação impessoal } \\
\text { Crítica do proletariado/ }\end{array}$ & $\mathrm{X}$ & $\mathrm{X}$ & $\mathrm{X}$ \\
luta de classes & & & $\mathrm{X}$ \\
$\begin{array}{l}\text { Teoria da Crise } \\
\text { (limite interno absoluto) }\end{array}$ & & & $\mathrm{X}$ \\
Crítica do Estado & & $\mathrm{X}$ & $\mathrm{X}$ \\
Crítica do mercado & & $\mathrm{X}$ & $\mathrm{X}$ \\
Crítica do antissemitismo estrutural & $\mathrm{X}$ & $\mathrm{X}$ & $\mathrm{X}$ \\
Crítica da dissociação sexual & & & $\mathrm{X}$ \\
Crítica do Iluminismo & & & $\mathrm{X}$ \\
Crítica da forma-sujeito & & & \\
\hline
\end{tabular}

Fonte: Elaboração própria, 2015.

No que se refere à luta de classes - uma "vaca sagrada" do marxismo tradicional -, ela é entendida por Postone e por Kurz como uma luta imanente ao sistema capitalista, sendo que ambos rejeitam a noção de um sujeito revolucionário a priori (de um “sujeito objetivo"). Quanto a Vincent, embora coloque a dominação impessoal no centro da sua análise, continua a mover-se num quadro teórico marcado pela luta de classes na medida em que atribui ao proletariado a "missão histórica" de abolir o capitalismo. Esta é, com efeito, uma das principais aporias do seu pensamento: negação do trabalho e, simultaneamente, afirmação da classe operária.

Postone foi pioneiro na teorização do "antissemitismo estrutural”, i.e., de uma crítica equivocada e reacionária do capitalismo que procura imputar os males desta sociedade a uma conspiração maquiavélica de um grupo social específico (POSTONE, 1986). Kurz foi igualmente responsável por importantes desenvolvimentos dessa teoria (KURZ, 2003a).

No que diz respeito à teoria da crise do capitalismo, Vincent é virtualmente omisso a esse respeito, visto que descarta a sua validade. Já Postone é no mínimo ambíguo: se, por um lado, o autor consegue captar a dinâmica de crise subjacente à contradição entre riqueza e valor, por outro lado parece rejeitar a "teoria do colapso", nomeadamente a de Kurz, como sendo demasiado “catastrofista” (POSTONE, 2012).

Nesse sentido, apenas Robert Kurz desenvolve aprofundadamente e de um modo 
original a teoria da crise de Karl Marx (KURZ, 2014b; 1995, 2004, 2012, 2013, 2014). Na sua opinião, o capitalismo começa a esbarrar com o seu "limite interno absoluto": a produção de mais-valia e a passagem da produção pelo buraco da agulha do valor são cada vez mais difíceis. É de realçar que apenas o "trabalho abstrato" produz valor econômico e é justamente o fosso entre as capacidades de produção de riqueza (mais uma vez, material e imaterial) e as capacidades minguantes de produção de valor que se acentua.

Cada aumento da produtividade provoca uma diminuição no valor unitário de cada mercadoria. A única maneira de contrabalançar a diminuição do valor contido em cada mercadoria individual é aumentar exponencialmente o volume de mercadorias produzidas, absorvendo com isso mais força de trabalho. Este foi o segredo por detrás da produção em massa da era fordista.

0 problema inaugurado pela chamada $3^{a}$ Revolução Industrial deriva, por um lado, do fato de os poderes de racionalização aumento sem precedentes da produtividade - passarem a suplantar o poder de expansão do mercado e, assim, comprometerem o mecanismo compensatório elencado.

Por outro lado, o aumento histórico da produtividade permitiu um embaratecimento generalizado da maioria dos bens essenciais (descontando, obviamente, a inflação), o que permitiu por sua vez reduzir os "custos de reprodução da força de trabalho" e, portanto, a parcela do "trabalho necessário" que representa os salários - contida em cada mercadoria. Este é o "segredo" subjacente à extração da mais-valia relativa (elemento basilar para a acumulação de capital no capitalismo maduro). Ora, a mais-valia relativa começar a enfrentar os seus limites históricos: a parcela do "trabalho necessário" con- tido em cada mercadoria já é de tal forma reduzida, que os constantes aumentos da produtividade apenas provocam aumentos homeopáticos na mais-valia produzida (i.e., da parcela do "trabalho excedente" produtor de mais-valia).

Como refere Marx, “o próprio capital é a contradição em processo, pelo fato de que procura reduzir o tempo de trabalho a um mínimo [através da concorrência], ao mesmo tempo que, por outro lado, põe o tempo de trabalho como única medida e fonte da riqueza” (MARX, 2011, p. 588-589).

Kurz salienta, contudo, que a dedução lógica da inevitabilidade da crise de reprodução da economia capitalista, ao contrário do que é comum criticar-se-lhe, não significa professar uma espécie de imobilismo: como o capitalismo entrará em colapso de qualquer maneira, podemos cruzar os braços e esperar confortavelmente. Ora, do colapso automático do capitalismo não decorre necessariamente a instauração de uma alternativa emancipatória, pois a construção do socialismo exige a ação coletiva, concertada e consciente dos seres humanos. 0 colapso do capitalismo apenas traz automaticamente uma coisa: a barbárie pura e simples a que já assistimos diariamente em várias zonas do globo.

Finalmente, a crítica do Iluminismo, a crítica da forma-sujeito e a crítica da dissociação sexualmente conotada apenas são elaboradas por Robert Kurz. Neste sentido, podemos concluir que a crítica do valor em "sentido amplo" apenas é empreendida, de fato, por Kurz e pelo Grupo Exit!.

\section{A relação entre o Gorz tardio e a Nova Crítica do Valor}

A trajetória intelectual de André Gorz foi extremamente sui generis. Como nota Jappe, 
Durante toda a sua vida [...] ele nunca cessou de colocar em questão as suas convicções anteriores. [...] [E]le esteve sempre pronto a reconhecer a insuficiência das suas abordagens pretéritas, mesmo que frequentemente as suas abordagens já fossem bastante mais avançadas do que aquelas dos seus contemporâneos. [...] Foi graças a esta disponibilidade para se questionar [...] que Gorz desenvolveu ainda, na derradeira fase da sua vida, concepções (discerníveis sobretudo na obra Ecologica) que se encontram entre as contribuições contemporâneas mais importantes para a renovação do pensamento de Karl Marx. Pelo menos no que respeita às fundamentações teóricas, as suas últimas ideias são mais radicais do que as suas ideias anteriores, e mais radicais do que quase tudo aquilo que hoje em dia passa por "anticapitalismo", mas que é em geral apenas uma critica insípida do neoliberalismo (JAPPE, 2013, p. 161, grifo nosso).

Nesse sentido, a última fase do seu pensamento - que compreende, grosso modo, a obra Gorziana da década de 2000 - reflete uma influência considerável da NCV (JAPPE, 2013). Schandl identifica igualmente esta relação entre os dois corpos teóricos: nos "últimos escritos de André Gorz [...] as suas posições [...] radicalizam-se”, sendo possível identificar "afinidades" com a NCV (SCHANDL, 2010, p. 1). ${ }^{7}$
Pode-se falar, com Jappe, de "uma convergência notável entre os fundamentos teóricos do último Gorz e aqueles da crítica do valor" (JAPPE, 2013, p. 165). Serão estas convergências que passarei agora a analisar com um pouco mais de detalhe. Em primeiro lugar, destaca-se o entendimento do trabalho como uma categoria historicamente específica, desconhecida antes do alvor da modernidade capitalista. Embora esta ideia não seja isenta de ambiguidades em Gorz, ${ }^{7}$ na sua formulação mais radical ela aproxima-se bastante do entendimento Postoniano e Kurziano do trabalho. Dessa forma, Gorz nos diz que

0 trabalho, tal como nós o entendemos hoje em dia, apenas nasceu com o capitalismo manufatureiro, seguidamente industrial. [...] Nas sociedades pré-capitalistas e pré-modernas, as atividades eram classificadas segundo a sua determinação particular e a sua posição hierárquica, não lhes sendo reconhecida nenhuma outra medida comum, nenhuma outra essência. [...] 0 conceito de trabalho tal como aparece em Hegel foi portanto uma revolução filosófica [...]. Ele designava a essência comum à totalidade das atividades mediante as quais o sujeito se inscreve e se objetiva na materialidade do mundo [...]. Ele designa a essência comum do conceber, do fazer, do fabricar e do agir que até então eram categorias incomensuravelmente distintas. [...] [E] ste conceito [...] apenas pôde surgir [...] quan-

6. A influência da NCV é igualmente reconhecida por Botelho (2009, p. 252), Harribey (2013, p. 172) e Navarro (2007, p. 112).

7. Nas décadas de 1980 e de 1990 (Gorz, 1989a, p. 13 e seguintes; 1994, p. 53 e seguintes), apesar dos esforços meritórios de Gorz para denunciar a naturalização das categorias capitalistas, a sua teoria é claramente contraditória a esse respeito. Se por um lado Gorz destaca a historicidade do trabalho, por outro lado distingue o "trabalho capitalista" de um suposto "trabalho pré-capitalista". Esta aporia é evidente na seguinte afirmação: "Não pode existir nenhuma sociedade, nenhuma vida, sem 'trabalho', mas nem todas as sociedades e vidas são baseadas no trabalho" (Gorz, 1989a, p.153). 
do o capitalismo manufatureiro deu origem a um proletariado de trabalhadores sem ofício, nem estatuto social e profissional, fornecedores de trabalho em geral, trabalho em si (ensoi), trabalho sem [qualquer] determinação particular. Com este proletariado [...] aparece pela primeira vez aquilo que Marx chamará de trabalho abstrato, trabalho-mercadoria, mensurável, quantificável, indiferente ao seu conteúdo, desvinculável dos indivíduos intercambiáveis que o realizam (GORZ, 2002a, p. 74 , grifo do autor).

Um segundo ponto de contato entre ambas as teorias é a apreensão da crise do trabalho (e por inerência, da crise do capitalismo). Enquanto "contradição em processo” (MARX, 2011, p. 588), “é o próprio capitalismo que abole o trabalho" (JAPPE, 2013, p. 165, grifo do autor), a "substância do capital” (KURZ, 2004). No contexto da $3^{\text {a }}$ Revolução Industrial - aquela da microeletrônica -, que permitiu um aumento sem precedentes da produtividade, a racionalização passa a superar o poder de expansão dos mercados. Doravante são necessárias quantidades cada vez menores de trabalho para produzir uma massa crescente de bens e serviços. Essa "situação [...] é agravada pela circunstância de que hoje em dia grande parte do trabalho [...] é "não produtivo"”, i.e., não produz mais-valia e, por conseguinte, não contribui para a "reprodução do capital” (JAPPE, 2013, p. 165).

Gorz já tinha diagnosticado a crise do trabalho durante a década de 1980 (GORZ, 1982; 1985), mas não tinha retirado daí as devidas consequências, acreditando que essa crise não acarretaria problemas de maior para a reprodução da esfera mercantil "heterônoma”, julgada insuperável.

Na década de 2000, Gorz identifica finalmente os "limites internos" da economia capitalista (ver o item 1.2) - em virtude da crise do trabalho -, o que corresponde a uma terceira convergência com a NCV: “a produção de valor coincide cada vez menos com a produção de "riqueza'" (JAPPE, 2013, p. 166). Neste sentido, "aquilo que aparece ainda como 'crescimento' deve-se à criação de créditos sem qualquer base real (qui ne sont fondés sur rien). A acumulação real [i.e., não fictícia] está em vias de se esgotar defınitivamente" (JAPPE, 2013, p. 166).

Ademais, se o trabalho é uma forma de atividade historicamente específica e fetichista, a sua crise não tem de representar forçosamente um cataclismo. Mais uma vez em linha com as proposições da NCV quarta convergência -, Gorz preconiza que a superação da crise do trabalho implica $a$ superação do próprio trabalho - no sentido hegeliano de aufhebung - assim como a abolição do valor (econômico) produzido pelo trabalho e da forma da mercadoria. De acordo com o autor,

Não superaremos estes limites [da economia capitalista] nem prática, nem teoricamente [par la pensée] enquanto nos mantivermos no terreno da produção de mercadorias, [...] enquanto continuarmos a confundir a produção de riqueza com a produção de valor; enquanto as pessoas continuarem a encerrar em si mesmas uma cisão entre consumidoras e produtoras, entre compradoras de mercadorias e vendedoras de trabalho; enquanto [...] [os indivíduos] não discernirem a possibilidade e não tiverem um interesse vital na subtração progressiva do seu consumo e do seu trabalho à forma da mercadoria, à forma do valor e na sua [própria] subtração ao capitalismo para conquistarem o poder sobre a determinação das suas necessidades e da sua vida. A reconstituição da unidade entre consumidores e produtores responde hoje 
em dia ao interesse vital e a uma necessidade vital tanto das populações do Norte como do Sul. [...]. A autoprodução fora do mercado [...] oferece [...] uma saída para escapar a esta determinação pelo capital do conteúdo das necessidades e do modo da sua satisfação (GORZ, 2007a, p. 10).

0 autor adverte, contudo, que o desenvolvimento de setores autônomos de “autoprodução não mercantil” não assumirá seguramente a forma de um "passeio tranquilo”, avançando, passo a passo, sem quaisquer entraves (GORZ, 2007a, p. 11). Ademais, este processo não é exequível apenas à "escala individual ou privada" (GORZ, 2007a, p. 10). Ele terá de ser levado a cabo por um "movimento social transnacional" capaz de coordenar as suas "prioridades estratégicas", nomeadamente a de abolir o trabalho e "emancipar a produção de riqueza das relações de valor" (GORZ, 2007a, p. 11).

De acordo com Gorz, o fundamento de qualquer crítica do capitalismo é constituído pela "violência contra si, pela repressão" inerentes ao funcionamento dos indivíduos de acordo com as "normas sociais e culturais dominantes" sob o capitalismo. A possibilidade de o indivíduo apreender e rejeitar o domínio onipresente do fetiche do capital terá de assentar na

décalage sentida, vivida, sofrida entre aquilo que devemos ser para poder funcionar [nesta sociedade] e aquilo que sentimos de um modo difuso. E a crítica deve começar por uma hermenêutica desta não-identidade consigo mesmo, que, sim, é mal-estar e sofrimento, revolta, recusa, aspiração virtuais que não possuem ainda [...] uma linguagem, uma forma de expressão para se entenderem reflexivamente. Ora, a sua expressão é a condição prévia de qualquer tentativa de transformação [social]. Porque ela eleva a subjetividade solitária e sofredora do vivido inefável ao estatuto de experiência comum, de ponto de partida para uma busca da ação coletiva e da de uma crítica dos valores dominantes à luz de valores diferentes (GORZ; VINCENT, 2012, p.4).

É de realçar que em Kurz o sofrimento imposto aos indivíduos pelas relações fetichistas capitalistas está igualmente no cerne da potencial rejeição desse mesmo fetichismo (REGATIERI, 2009). Todavia, contrariamente à esmagadora maioria da esquerda, Gorz não postula a existência apriorística de um sujeito coletivo revolucionário que já é,em si, a negação da sociedade capitalista - chame-se-lhe proletariado, multidão ou aquilo que se queira. Neste aspecto é evidente a quinta afınidade entre a teoria Gorziana e aquela da NCV. ${ }^{8}$

0 sexto ponto de convergência entre a teoria Gorziana e aquela da NCV é a noção de que "o capitalismo não se carateriza, fundamentalmente, pela dominação de uma classe sobre a outra, através da propriedade privada dos meios de produção" (JAPPE, 2013, p. 166, grifo do autor). Pelo contrário, o capitalismo "consiste na dominação anónima exercida por categorias fetichistas: valor, mercadoria, dinheiro, trabalho, capital, Estado, mercado" (JAPPE, 2013, p. 166).

8. Na década de 1980 Gorz já tinha observado que os "interesses, capacidades e competências" da classe operária são completamente "funcionais" relativamente ao desenvolvimento capitalista (GORZ, 1982, p. 15), i.e., não corporizam uma sociabilidade contrária às categorias mercantis. 
A esse respeito Gorz realça que

Não é o "eu" que age, mas a lógica automatizada dos sistemas sociais que funciona através de mim enquanto Outro, que me faz participar na produção e reprodução da megamáquina social. Essa lógica é o verdadeiro sujeito. E o estrato social dominante sofre a sua dominação tanto como os [estratos] dominados ${ }^{9}$ (GORZ, 2010a, p. 4).

Finalmente, em sétimo lugar, seguindo a teoria da NCV, Gorz defende que a crítica exclusiva da "especulação financeira" e do sistema bancário é uma crítica "reduzida" (trop court) do capitalismo que, ademais, pode degenerar em "formas bastante perigosas de populismo" de cariz antissemita (JAPPE, 2013, p. 167).

Apesar de todas essas semelhanças, existem “diferenças assinaláveis" (JAPPE, 2013, p. 168) entre a teoria de Gorz e aquela da NCV, nomeadamente:

i) Quanto à concepção de trabalho “A categoria marxiana de 'trabalho abstrato' [...] permanece de certo modo sub-explorada em Gorz", que muitas vezes se limita a criticar o "'trabalho mercantil' ou 'trabalho-emprego"” (JAPPE, 2013, p. 165-166);

ii) Quanto à apreciação da tecnologia

- Gorz tende a postular "a natureza 'não mercantil' da informática (que Kurz nega) e a possibilidade de desenvolver a partir da mesma 'ilhas' subtraídas à lógica mercantil” (JAPPE, 2013, p. 168). Jappe salienta ainda o entusiasmo desenfreado de Gorz face ao software livre e à "autoprodução high-tech" (JAPPE, 2013, p. 168) em 0 Imaterial;

iii) Quanto às "perspectivas 'práticas"” (JAPPE, 2013, p. 168) de emancipação do capitalismo - subsiste em Gorz um certo grau de voluntarismo e de "praticismo" herdado do marxismo tradicional, pelo que a teoria tende a ser encarada de um modo instrumental: o seu principal objetivo é (quase) sempre encontrar imediatamente alternativas concretas à racionalidade econômica capitalista (ver, por exemplo, GORZ, 2005a, p. 63-69). Em suma, como refere Jappe,

o desejo constante de Gorz de encontrar soluções "concretas" e "pragmáticas" e a questão da "transição" [para o socialismo] [...] podem tê-lo forçado a abandonar demasiado rápido o patamar da reflexão radical sobre a essência do sistema mercantil, em benefício de proposições sobre as formas [práticas] de superar esse sistema que confiam demasiado no papel dos meios técnicos, quando, na verdade, é a forma das relações sociais que determina o papel que os meios técnicos podem desempenhar (JAPPE, 2013, p. 168).

Para além desses elementos, é de realçar a ausência, em Gorz, de vários aspectos centrais na teoria de Robert Kurz e do Grupo Exit!, i.e., daquilo que designei por

9. Na década de 1980, Gorz já tinha caracterizado a dominação vigente no capitalismo como uma dominação impessoal, mas a sua origem permanece ambígua: por vezes, o autor é capaz de discernir a origem da dominação impessoal capitalista na sua forma de organização social, nomeadamente na desvinculação e autonomização da economia e das categorias a ela associadas (valor, mercadoria, trabalho etc.). Contudo, em outras ocasiões, Gorz faz da tecnologia, literalmente, uma espécie de Deus exmachina à qual é possivel reconduzir todos os malefícios do capitalismo. 
crítica do valor "em sentido amplo" (ver os itens 2.3 e 2.4);

iv) Uma crítica do Iluminismo - na esteira de Habermas, Gorz nega a crise da modernidade e da razão iluminista (GORZ, 1994, p. 1-14 e 24-25). Gorz critica apenas a ingerência da "racionalidade econômica" em todos os domínios de atividade. $\mathrm{Na}$ ótica de Kurz, contudo, a modernidade, o Iluminismo e o capitalismo são concomitantes e coextensivos. 0 Iluminismo é a (ir) racionalidade historicamente específica do sistema produtor de mercadorias da modernidade. Nesse sentido, a emancipação da humanidade exige a abolição desta "razão sangrenta" e totalitária, e a instauração de uma "razão sensível” (KURZ, 2002);

v) Uma crítica da forma-sujeito - Gorz assume de maneira não problemática o sujeito como o ponto de apoio para a superação do capitalismo (embora rejeite a noção de um sujeito coletivo apriorístico). Ora, de acordo com Kurz a forma-sujeito não é de modo algum neutra: o sujeito moderno é estruturalmente masculino, branco, ocidental (MBO), monetário e concorrencial. A superação do capitalismo implica que os indivíduos sejam capazes de pensar contra si mesmos enquanto sujeitos socializados pelas categorias capitalistas, enquanto sujeitos cuja conduta é pautada por modos de ser e de agir fetichistas; por outras palavras, a superação do capitalismo implica a superação da forma-sujeito moderna;

vi) Uma crítica consequente da dissociação sexualmente conotada - embora Gorz identifique esta cisão (GORZ, 1982, p. 5-6 e 82-86), não é capaz de pensar a sua supe- ração efetiva; em vez disso, parece afirmar unilateralmente um dos polos - o "feminino" -, atribuindo-lhe imediatamente um potencial emancipatório.

Todavia, apesar destas lacunas, um dos aspectos que torna André Gorz um teórico singular é o fato de que nunca se coibiu de reconhecer que estava errado e de rever as suas posições anteriores. Aliás, na correspondência que manteve nos últimos anos de vida com vários autores da NCV ${ }^{10}$ transparece uma grande humildade e o enorme desejo de entender na plenitude as ideias desta corrente - em particular as de Robert Kurz - que sente estarem num patamar de reflexão superior às suas próprias ideias (JAPPE, 2013, p. 164).

Nessa correspondência, Gorz confessará com algum desgosto que "foi já bastante tarde que eu descobri a corrente da crítica do valor" (GORZ apud JAPPE, 2013, p. 164). Conforme salienta Schandl, a descoberta de um corpus teórico mais radical do que o seu - e que, no seu entendimento, providenciava uma análise crítica mais adequada do capitalismo - fez com que, "no seu último livro e nas suas últimas cartas”, Gorz falasse "muitas vezes sob a forma de uma autocrítica" (SCHANDL, 2010, p. 5).

Por exemplo, quando é instado a publicar novas edições dos seus livros, entretanto esgotados, Gorz responde a Schandl da seguinte forma:

Na tua última carta é sugerida a possibilidade de uma reedição de alguns livros meus que se encontram esgotados. Eu examinei-os rapidamente e tenho a sensação de que, pa-

10. A revista austríaca Streifzüge publicou excertos desta correspondência de Gorz com vários autores associados à NCV (GORZ, 2007b). Todavia, devido ao fato de eu não ler alemão, apenas consegui aceder indiretamente a essa correspondência, através dos trechos citados por AnselmJappe e Franz Schandl. 
ra além daquilo que ainda permanece válido (valable), eles contêm muitas (demasiadas) coisas obsoletas. Eu preferiria tentar organizar uma coletânea de textos agrupados de forma temática, que não excederia as 300 páginas. (GORZ apud SCHANDL, 2010, p. 1)

0 fato a reter é que Gorz considera agora que a maioria dos seus escritos estão "obsoletos", nomeadamente o conceito de "sociedade dual" - central nas décadas de 1980 e 1990 - e a noção de um rendimento básico, que passa a ser entendido como uma mera medida de emergência (GORZ, 2007a).

Parece-me, contudo, que a autocrítica de Gorz peca claramente por excesso. Botelho assinala a importância das teses defendidas pelo último Gorz que, afınal de contas, não andam assim tão longe da teoria preconizada pela NCV:

[A] discussão sobre o colapso da produção baseada no valor serve a André Gorz para iniciar uma reflexão muito rica e importante [...]. Trata-se da necessidade premente em desvincular o conceito de riqueza do conceito de valor. Assim como a produção social não precisa necessariamente assumir a forma de trabalho, também a riqueza não precisa passar pela forma valor e, portanto, tornar-se mercadoria para ser socialmente desfrutada. (BOTELHO, 2009, p. 254)

A morte de Gorz, em setembro de 2007, colocaria um fim prematuro a esse intercâmbio teórico com a NCV. Assim, ninguém poderá dizer, com certeza, qual seria o rumo tomado pelo pensamento Gorziano. Todavia, a sua longa trajetória intelectual permite-nos conjeturar que o autor nunca cessaria de reinventar a sua teoria.

\section{Considerações Finais}

[E]ntre riqueza e "valor" abriu-se um abismo cada vez mais profundo. [...] [0] sentido e [a] qualidade de vida dependem em escala crescente de riquezas particulares, que não podem ser geradas e adquiridas sob a forma de mercadorias e valor. Pelo contrário, elas podem surgir somente através da atividade livre, que não tem como finalidade nem a multiplicação nem a aquisição de dinheiro (GORZ, 2005a, p. 72).

$\mathrm{Na}$ década de 2000, o pensamento de André Gorz sofreu uma nova radicalização, algo bastante invulgar no percurso teórico de um autor com uma idade tão avançada. Se na década de 1990 o seu pensamento foi caracterizado por um certo reformismo e pessimismo (GORZ, 1994; 1999a), nos seus dois últimos livros a superação do capitalismo volta a entrar na agenda de Gorz. Segundo Jappe,

Esta radicalização [...] não deve ser dissociada da sua descoberta das teorias de Robert Kurz, de Moishe Postone e de outros autores que são agrupados geralmente sob a designação de "crítica do valor". Ele [Gorz] cita-os de um modo bastante apologético nos seus últimos textos [...] e manteve uma correspondência profícua com muitos autores da crítica do valor, na qual exprime o seu lamento por não ter descoberto mais cedo esta corrente, da qual se sentia uma espécie de “membro". (JAPPE, 2013, p.163-164)

Fourel e Gollain fazem uma leitura semelhante:

A partir de 2003-2004, ele radicaliza ainda mais a sua posição [teórica] quando se apercebe da grande afınidade [do seu pensamento] com a corrente marxista denominada por 
"crítica do valor", representada nos Estados Unidos por Moishe Postone e no espaço germanófono por Robert Kurz e pelos grupos Krisis e Exit!. (FOUREL; GOLLAIN, 2013, p. 9)

À semelhança dessa corrente, Gorz insurge-se contra "a naturalização do valor económico" (PERRET, 2013, p. 117). A eliminação progressiva do trabalho abstrato, na sequência da $3^{\text {a }}$ Revolução Industrial, significa que o valor econômico é virtualmente abolido (GORZ, 2005a, p.38). "A criação de riqueza já não pode ser medida em termos monetários", pelo que "deve ser desatrelada da criação de valor" (GORZ, 2005a, p. 57). A mercadoria e o dinheiro não se aplicam a um mundo em que o padrão de medida da riqueza já não é o tempo de trabalho (GORZ, 2005a, p. 13). Em outros termos, o capitalismo atingiu o seu limite interno absoluto.

Para além da crise do trabalho - a substância do valor - Gorz associa a crise estrutural capitalista ao papel preponderante adquirido pelo conhecimento no processo produtivo. De acordo com Gorz, o capitalismo procurou ultrapassar a crise do regime fordista através do desenvolvimento de uma "economia do conhecimento" (GORZ, 2010a, p. 178). Todavia, a mercadorização do conhecimento é problemática, pois o seu valor é sempre um "constructo artificial". Ora, "se a força produtiva decisiva (da inteligência, do conhecimento) não é suscetível de se tornar uma mercadoria” (GORZ, 2010a, p.12), o capitalismo cognitivo é um capitalismo que enfrenta a crise das suas categorias fundamentais - trabalho, valor e capital (GORZ, 2005a, p. 59).

Em linha com as proposições da NCV, Gorz destaca ainda que esta crise estrutural é ilustrada pela importância crescente da "indústria financeira". Desde o início da década de 1980, as transações financeiras representam uma soma de dinheiro superior à dos capitais investidos na produção de mercadorias. Porém, a explosão do capital fictício é um sintoma, e não a causa, da crise econômica. As dificuldades de acumulação na "economia real" levam o capital a simular a sua acumulação na esfera financeira, através de bolhas sucessivas. Assiste-se a uma criação sem precedentes de uma enorme massa monetária sem qualquer substância, inteiramente fictícia (GORZ, 2007a, p. 4).

Assim, é apenas uma questão de tempo até que as bolhas especulativas rebentem e, com elas, o "poder de compra" artificial que sustenta a produção e a compra de mercadorias na economia real. 0 cerne da questão é que os meios de produção, a força de trabalho e as matérias-primas deixaram simplesmente de ser utilizáveis de acordo com os critérios da racionalidade capitalista, i.e., de um modo rentável - capaz de reproduzir e fazer crescer o capital investido (GORZ, 2007a, p. 4).

Podemos concluir que a visão de uma sociedade pós-capitalista que emerge da teoria do último Gorz é, pois, a de uma sociedade pós-mercantil em que o trabalho, o valor, a mercadoria e o dinheiro deverão ser completamente abolidos, o que se coaduna perfeitamente com a teoria da NCV.

Todavia, como tivemos oportunidade de salientar (ver seção 3), existe também um conjunto divergências entre a teoria Gorziana e aquela da NCV. Uma dessas divergências prende-se com o entendimento da tecnologia: Gorz tende a atribuir à informática e à microeletrônica um caráter imediatamente não mercantil (algo que a NCV nega).

Para além disso, a concepção da teoria também é distinta. Se a NCV, na sequência de Adorno, realça a importância da auto- 
nomia da teoria, Gorz, por seu turno, é refém de um certo grau de voluntarismo e de "praticismo", pelo que a teoria tende a ser encarada de um modo instrumental.

Finalmente deve ser realçada a ausência, em Gorz, de várias dimensões basilares para a crítica do valor "em sentido amplo": a crítica do Iluminismo, enquanto racionalidade subjacente ao capitalismo, ou seja, uma razão que traduz modos de ser/agir/ pensar apriorísticos e fetichistas; a crítica do forma-sujeito, porquanto o sujeito moderno interioriza as categorias capitalistas através da sua socialização; e a crítica cabal da dissociação sexual, consubstanciada na dominação estrutural masculina.

\section{Referências}

BOTELHO, M. L. Crise da sociedade do trabalho: teorias em conflito. Tese (Doutorado em Desenvolvimento, Agricultura e Sociedade) - Universidade Federal Rural do Rio de Janeiro, Instituto de Ciências Humanas e Sociais, Rio de Janeiro, 2009.

CAMIC, C.; GROSS, N. The New Sociology of Ideas. In: BLAU, J. R. (Org.). The Blackwell Companion to Sociology. 2nd ed. Malden, Oxford e Carlton: Blackwell Publishing, p. 236-249, 2004.

CASTEL, R. A. G. et le travail: une interprétation critique. In: CAILLÉ, A.; FOUREL, C. (Org.). Sortir du capitalisme: Le scénario Gorz. Paris: Le Bord de L'eau, p. 43-56, 2013.

FOUREL, C.; GOLLAIN, F. André Gorz, penseur de l'émancipation. La Vie des Idées, 3 dez. 2013. Disponivel em: http://www.laviedesidees.fr/IMG/pdf/ 20131203 gorz1-2.pdf. Acesso em: 12 dez. 2014.

GOLLAIN, F. Une critique du travail: entre écologie et socialisme. Paris: Éditions La Découverte, 2000.

GORZ, A. Farewell to the Working Class: An essay on Post-Industrial Socialism. London: Pluto Press, 1982.
Paths to Paradise: On the Liberation from Work. London: Pluto Press, 1985/1983.

Critique of Economic Reason. London: Verso, 1989a.

Capitalism, Socialism, Ecology. London: Verso, 1994.

. Reclaiming Work: Beyond the Wage-Based Society. Cambridge: Polity Press, 1999a/1997.

. Ecologie et Socialisme. Ecologie et Politique, n. 24, p. 71-95, 2002a.

. Valeur et richesse: le divorce. Transversales, Nouvelle Série, n.3, p. 44-46, 2002b.

. Économie de la connaissance, exploitation des savoirs. Multitudes, n.15, 2004. p. 205-216.

. 0 imaterial: conhecimento, valor e capital. São Paulo: Annablume, 2005a.

André Gorz: différence entre "valeurs» et "richesses», 2005b. Disponivel em: https://nunomiguelmachado.files.wordpress.com/2012/01/ entrevista-diffc3a9rence-entre.pdf . Acesso em: 12 dez. 2014.

Se libérer du travail?. 2005c. Disponível em: http://www.perspectives-gorziennes.fr/public/ pdf/Morceaux_choisis_d_Andre_GorzWWW.pdf.. p.55-57. Acesso em: 24 fev 2014.

Où va l'écologie? Le Nouvel Observateur, n.14 dez. 2006. Disponível em: https://nunomiguelmachado.files.wordpress.com/2012/01/entrevista-oc3b9-va-lc3a9cologie.pdf. Acesso em: 12 dez. 2014.

Penser l'exode de la société du travail et de la marchandise. Mouvements, n.50, 2007a. Disponível em: https://nunomiguelmachado.files. wordpress.com/2012/01/16-penser-lexode. pdf. Acesso em: 12 dez. 2014.

Überden Horizontunserer Handlungen Ausdennachgelassenen Briefendes André Gorz. Streifzüge, n.21, p. 9-13, 2007b.

Ecologica. London: Seagull Books, 2010a. 
Political Ecology between Expertocracy and Self-Limitation. In: GORZ, André. Ecologica. London: Seagull Books, p. 43-76, 2010 b.

GORZ, A.; VINCENT, J. M. Correspondance. Variations, n. 17, 2012/2000-2. Disponivel em: https://nunomiguelmachado.files.wordpress. com/2012/01/9-1-correspondc3a ancia-gorz-vincent-pdf-2000-2002.pdf. Acesso em: 12 dez. 2014.

HARRIBEY, J. M. Faut-il faire disparaître la valeur pour sortir du capitalisme? Discussion autour de Gorz. In: CAILLÉ, A.; FOUREL, C. (Orgs.). Sortir du capitalisme: Le scénario Gorz. Paris: Le Bord de L'eau, 2013. p. 171-187.

JAPPE, A. As Aventuras da Mercadoria: Para uma nova crítica do valor. Lisboa: Antígona, 2006.

André Gorz et la critique de la valeur. In: CAILLÉ, Alain; FOUREL, Christophe (Orgs.). Sortir du capitalisme: Le scénario Gorz. Paris: Le Bord de L'eau, p. 161-169, 2013.

KURZ, R. Dominação sem sujeito: sobre a superação de uma crítica social redutora. Krisis, n.13, 1993. Disponivel em: http://obeco.planetaclix.pt/ rkurz86.htm. Acesso em: 17 maio 2013.

. 0 fim da política: s sobre a crise do sistema de regulação da forma da mercadoria. Krisis, n.14, 1994. Disponivel em: http://obeco.planetaclix.pt/rkurz105.htm. Acesso em: 17 jun. 2014.

A ascensão do dinheiro aos céus: os limites estruturais da valorização do capital, o capitalismo de casino e a crise financeira global. Krisis, $n$. 16/17, 1995. Disponivel em:http://o-beco.planetaclix.pt/rkurz101.htm. Acesso em: 13 mai. 2013.

O colapso da modernização: da derrocada do socialismo de caserna à crise da economia mundial. 5. ed. São Paulo: Paz e Terra, 1999.

As leituras de Marx no século XXI. 2001. Disponivel em: http://obeco.planetaclix.pt/ rkurz97.htm. Acesso em: 16 mar. 2014.

Razão sangrenta: 20 teses contra o chamado Iluminismo e os "Valores Ocidentais". Krisis, n.25, 2002. Disponivel em: http://obeco.planetaclix.pt/rkurz103.htm. Acesso em: 16 mar. 2014.
As perfídias do capital financeiro: limites internos da acumulação, crítica reduzida do capitalismo e síndroma anti-semita. Streifzüge, n.3, 2003a. Disponivel em: http:// obeco.planetaclix. pt/rkurz159.htm. Acesso em: 17 jun. 2014.

Ontologia Negativa: As eminências pardas do Iluminismo e a metafísica histórica da Modernidade. In: Krisis, n.26, 2003b. Disponivel em: http://obeco.planetaclix.pt/ rkurz115.htm. Acesso em: 16 mar. 2014.

Tábula rasa: até onde é desejável, obrigatório ou lícito que vá a crítica ao Iluminismo? In: Krisis, n.27, 2003c. Disponível em: http://obeco.planetaclix.pt/rkurz153.htm. Acesso em: 16 mar. 2014.

A substância do capital: o trabalho abstracto como metafísica real social e o limite interno absoluto da valorização. Primeira Parte: A qualidade histórico-social negativa da abstracção trabalho. EXIT! Krise und Kritik der Warengesellschaft, 1, 2004. Disponivel em: http://obeco. planetaclix.pt/rkurz203.htm. Acesso em: 13 maio 2014.

Razão sangrenta: ensaios sobre a crítica emancipatória da modernidade capitalista e de seus valores ocidentais. São Paulo: Hedra, 2010.

Crise e crítica: o limite interno do capital e as fases do definhamento do marxismo. Um fragmento. Primeira parte. EXIT! Krise und Kritik der Warengesellschaft, n.10, 2012. Disponivel em: http://o-beco.planetaclix.pt/rkurz409.htm. Acesso em: 25 jan. 2015.

Crise e crítica: o limite interno do capital e as fases do definhamento do marxismo. Um fragmento. Segunda parte. EXIT! Krise und Kritik der Warengesellschaft, n.11, 2013. Disponivel em: http://o-beco.planetaclix.pt/rkurz410.htm. Acesso em: 25 jan. 2015.

Dinheiro sem valor: linhas gerais para uma transformação da crítica da economia política. Lisboa: Antígona, 2014a.

The Crisis of Exchange-Value: Science as Productive Force, Productive Labor, and Capitalist Reproduction. In: LARSEN, Neil et al. (Org.). Mar- 
xism and the Critique of Value. Chicago e Alberta: MCM' Publishing, 2014b/1986, p. 17-75.

LAMAS, B. Apresentação do ensaio "O Valor é o Homem" de Roswitha Scholz e da teoria da dissociação-valor. 2011. Disponivel em: http://o-beco.planetaclix.pt/bruno-lamas.htm. Acesso em: 17 jun. 2014.

Marx, K. O Capital: Crítica da Economia Política. Livro Primeiro. 3. ed. São Paulo: Editora Nova Cultural, 1996.

MARX, K. Grundrisse: Manuscritos Econômicos de 1857-1858. Esboços da Crítica da Economia Política. São Paulo: Boitempo Editorial, 2011.

NAVARRO, J. V. André Gorz, perfil político y filosófico de un intelectual dissidente. In memoriam. Revista Internacional de Filosofia Política, n.30, 2007, p. 101-116.

PERRET, B. Penser avec et contre André Gorz. Individualisme révolutionnaire $v s$ éthique de la responsabilité. In: CAILLÉ, A.; FOUREL, C. (Org.). Sortir du capitalisme: Le scénario Gorz. Paris: Le Bord de L'eau, 2013, p. 117-126.

POSTONE, M. Necessity, Labor and Time: A Reinterpretation of the Marxian Critique of Capitalism. Social Research, n.45 (4), 1978. p. 739-788.

Anti-Semitism and National Socialism. In: RABINBACH, A.; ZIPES, J. (Org.). Germans and Jews since the Holocaust: The Changing Situation in West Germany. New York: Homes and Meier, 1986, p. 97-115.

Time, Labor, and Social Domination: A Reinterpretation of Marx's Critical Theory. 2nd. ed. Cambrige/New York: Cambridge UniversityPress, 2003.

Para una Teoría Crítica del Presente: En Conversación com Moishe Postone sobre las Nuevas Lecturas de Marx, la Crisis y el Antisemitismo. Constelaciones - Revista de Teoría Crítica, n.4, p. 376-403, 2012.

QUIVY, R.; CAMPENHOUDT, L. V. Manual de Investigação em Ciências Sociais. 4. ed. Lisboa: Gradiva, 2005.
REGATIERI, R. P. Negatividade e ruptura: configurações da crítica de Robert Kurz. 2009. 110f. Dissertação (Mestrado em Sociologia) - FFLCH - Universidade de São Paulo, São Paulo, 2009.

SCHANDL, F. Antiéconomie: André Gorz et la critique de la valeur, 2010. Disponivel em:http://sd-1.archive-host.com/membres/up/4519779941507678/ Gorz_expos_Franz_pdf.pdf Acesso em: 2 mar. 2014.

SCHOLZ, R. 0 valor é o homem: teses sobre a socialização pelo valor e a relação entre os sexos. Novos Estudos, n.45, p.15-36, 1996.

SKINNER, Q. Meaning and Understanding in the History of Ideas. History and Theory, n.8 (1), p. 3-53, 1969.

SOUTHGATE, B. Intellectual history/history of ideas. In: BERGER, S. ; FELDNER, H.; PASSMORE, K. (Org.). Writing History: Theory and Practice. London: Hodder Arnold, 2003, p. 243-260.

VINCENT, J. M. La domination du travail abstrait. Critiques de l'économie politique, Nouvelle Série, n.1, p. 19-49, 1977.

Les mensonges de l'État. Paris: Éditions Le Sycomore, 1979.

. Critique du Travail: Le faire et l'agir. Paris: Presses Universitaires de France, 1987.

Acumulação do capital. In: BOUDON, Raymond et al (Org.). Dicionário de Sociologia. Lisboa: Publicações Dom Quixote, 1990a, p. 13.

. Marx (Karl). In: BOUDON, Raymond et al. (Org.). Dicionário de Sociologia. Lisboa: Publicações Dom Quixote, 1990b, p. 151-152.

. Liberar la producción, pero también liberarse de la producción. Viento Sur, n.17, 1993, p. 65-74.

Un Autre Marx: Après les marxismes. Lausanne: Editions Page Deux, 2001.

. Pensar en Tiempos de Barbarie: La Teoría Crítica de la Escuela de Frankfurt. Santiago: Universidad ARCIS, 2002. 
RESUMO

A tese fundamental deste artigo é que existe uma relação estreita entre a obra tardia de André Gorz e a Nova Crítica do Valor (NCV). Em particular, a radicalização do pensamento de Gorz deveu-se, sobretudo, à descoberta da NCV. Esta corrente tem raízes na crítica da economia política de Marx e na teoria crítica da Escola de Frankfurt. Os seus principais representantes são Jean-Marie Vincent, Moishe Postone e Robert Kurz. Através de uma análise comparativa dos vários autores, serão aferidas as convergências (e as divergências) que se estabelecem entre ambas as teorias. Gorz adotou a distinção entre valor e riqueza da NCV, assim como a teoria da crise Kurziana, nomeadamente a noção de um limite interno absoluto da produção capitalista. Todavia, subsistem várias diferenças entre a sua teoria e aquela da NCV, nos âmbitos do conceito de tecnologia, do papel atribuído à teoria, da crítica do Iluminismo, da teoria do sujeito e da teoria da dissociação sexual.

\section{PALAVRAS-CHAVE}

Gorz. Vincent. Postone. Kurz. Nova Crítica do Valor.

\section{ABSTRACT}

The main thesis of this article is that there is a close relation between the late work of André Gorz and the New Critique of Value (NCV). Particularly, the discovery of the NCV played a decisive role in the radicalization of Gorz's thought. This current is grounded on Marx's critique of political economy and on the critical theory of the Frankfurt School. Its major authors are Jean-Marie Vincent, Moishe Postone and Robert Kurz. Through a comparative analysis of the mentioned authors, the similarities (and dissimilarities) between both theories will be assessed. Gorz adopted the NCV's distinction between value and wealth, as well as Kurz's crisis theory, namely the notion of an absolute internal limit to capitalist production. Nevertheless, there are several differences between Gorz's theory and the theory of the NCV, regarding: the concept of technology, the role played by theory, the critique of enlightenment, the theory of the subject and the theory of sexual dissociation.

\section{KEYWORDS}

Gorz; Vincent. Postone. Kurz. New Critique of Value. 